\title{
Physicochemical properties, vitamins, antioxidant activities and amino acid composition of ginger spiced maize snack 'kokoro' enriched with soy flour (a Nigeria based snack)
}

\author{
Fasasi Olufunmilayo Sade*, Alokun Omotayo Aderonke \\ Department of Food science and Technology, Federal University of Technology, Akure, Nigeria; *Corresponding Author: \\ sadefunmi71@gmail.com
}

Received 2013

\begin{abstract}
Blends of white maize, ginger powder (white and yellow) and soy flour were prepared at the following ratio of white maize 97\%: yellow ginger 3\% (WM /YG); white maize 97\%: white ginger 3\% (WM/WG); white maize $87 \%$ : soy bean $10 \%$ : yellow ginger 3\% (WM/S/YG); white maize $87 \%$ : soy bean 10\%: white ginger 3\% (WM/S/WG), white maize $90 \%$ : soybean $10 \%$ (WM/S), white maize $100 \%$ (WM) control. As result revealed protein content, energy value, ash contents of ginger spiced 'kokoro' improved significantly with the addition of ginger spice and or soy flour compared with the control. The mineral composition of ginger spiced 'kokoro', increased significantly at $p<0.05$ especially with WM/S. Addition of ginger and or soy improves the vitamin $A$ and C content of ginger spiced 'kokoro', WM/S/YG had the highest vitamin A. while WM/S/WG had the highest Vitamin $C$ content as compared with the control (WM). Result revealed that WM/S/YG displayed the highest DPPH radical scavenging actives. Significant $(p<0.05)$ improvement was observed in the amino acid content of the ginger spiced 'kokoro'. The addition of ginger powder and or soy flour decreases the load at break (N), compressed Extension at Break $(\mathrm{mm})$, and the energy at break (J) of the ginger spiced 'kokoro'.
\end{abstract}

Keywords: Maize; Ginger Powder; Soy Flour; Snacks

\section{INTRODUCTION}

Snacks are becoming popular most especially in the urban cities due to the fact that most people now work far away from their homes. The annual production of maize in Nigeria is about 5.6 million tones [1]. It is prepared and consumed in a multitude of ways which vary from region to region or from one ethnic group to the other. They are also used for the production of different convenience snack foods which are eaten to prevent hunger before the main meals or just (as relish) for the fun of eating them. Maize are deficient in sulphur amino acids such as lysine hence the need to compliment maize with legumes such as groundnuts and soybeans which are better sources of the sulphur amino acids [2]; Ameida-Dominguez et al,[3] reported an improved balance of amino acids in the products made from such combination. Omueti and Morton [4] reported that snack does not provide nutrients in adequate quantities needed by the body, which is due to their composition or due to the production process. Whatever might have been responsible for their poor nutritional content, it is necessary to ensure that food consumed as main meal or snack contain required nutrients in adequate amounts, this is important because many people now work outside their homes due to urbanization and are becoming more dependent on snacks for the supply of part of their daily nutritional requirements. It is therefore necessary to produce a highly acceptable snack with high nutritional quality that could be useful in nutritional programmes to combat malnutrition and nutrient deficiencies [5]. Ginger (Zingiber officinale) is a spice believed to be indigenous to South East Asia, from where it has spread to other tropical regions of the world [6]. Other major producers include India, Nigeria, Sierra Leone, Jamaica, China and Haiti [7]. The extracts of ginger have multiple pharmacological effects, cardiotonic effects, gastro-intestinal actions thermogenic, and antibiotic activities they are also important as digestive stimulants [8]; Ginger is used in food, beverages and confectionary [9]. Kokoro' is a popular local snack in South Western Nigeria made from maize flour. It is widely accepted in Southwestern Nige- 
ria; it is inexpensive compared to other snacks because of its relatively low cost of production. It is widely accepted among children and adults as a product that is consumed on such a wide scale; it could be a convenient vehicle for the desired nutritional and antioxidant properties. The study aims at investigating the physicochemical properties, amino acid composition and antioxidant properties of 'kokoro' substituted with soy flour and ginger spice.

\section{MATERIALS AND METHODS}

\subsection{Materials}

Maize, ginger (white and yellow Zingiber officinale); soybean (Glycine max); refined vegetable oil; onions and salt used in this study were purchased, from a local market in, Akure, Nigeria.

All chemical used were of analytical grades.

\subsection{Methods}

\section{Production of Soybean flour}

Soybeans flour was produced using the method described by [10], with little modification. Soy bean were sorted cleaned manually. The clean seeds were soaked in water for $2 \mathrm{hrs}$ and boiled in water at $(100 \pm 2){ }^{\circ} \mathrm{C}$ for 20 mins. The blanched soybeans were dehulled manually and drained. The decorticated seeds were oven (Model DHG-9101.I SA) dried at $(60 \pm 5)^{\circ} \mathrm{C}$ for $8 \mathrm{hrs}$. The dried cotyledons were dry milled using an attrition mill. Flour obtained was sieved using sieve of $150 \mu \mathrm{m}$.

Processing of ginger powder

Ginger roots used were cleaned, peeled, cut, wash and dried at $(60 \pm 2){ }^{\circ} \mathrm{C}$ for $10 \mathrm{hrs}$ in an oven (Model DHG9101.ISA). Dried ginger was milled and sieved using $150 \mu \mathrm{m}$ to obtain a powdery form.

Production of Ginger Spiced 'Kokor'

A preliminary study on the traditional production of 'kokoro' was carried out in Imasayi Yewa South Local government area of Ogun-State where 'kokoro' production is their major source of income. The traditional method of 'kokoro' production was used with a slight modification. The maize grains were manually cleaned and were cooked (boiled) till soft and dewatered. The cooked grains were cooled over night and wet milled. 40 $\mathrm{g}$ of milled onions (the onions were peeled, cut and wet milled) were added immediately after milling. $2 \mathrm{~g}$ of salt was added to the dough (common salt was added to the control 'kokoro' while rock salt was added to the remaining dough). Dough was gently mixed into a stainless steel pot, depending on the ratios. Soybean flour and ginger were added as appropriate the mixture was continuously mixed until stiff dough is formed. The mixed dough was kneaded, rolled for $5 \mathrm{~min}$ on a chopping board; cut out into pieces and rolled into ring shape on a chopping board; the rings were deep fried in hot vegeta- ble oil at $(150 \pm 2)^{\circ} \mathrm{C}$ for $10 \mathrm{~min}$. It was kept overnight to cool and fried again the next day at $(150 \pm 2)^{\circ} \mathrm{C}$ for 3 min till a white crispy color was obtained. It was cooled and packed into a sealed polyethylene bags and kept at 4 ${ }^{\circ} \mathrm{C}$ before use.

The formulations were prepared using the following blend ratio.

Proximate composition of the 'kokoro' was determined as described by AOAC [11]. Carbohydrate was calculated by difference. Energy was calculated using Atwater factor. The Calcium, Sodium, Magnesium and Potassium contents were determined by flame photometry [11]. The concentration of Iron was determined after wet digestion with a mixture of perchloric and nitric acid using Atomic Absorption Spectrophotometry (AAS, Model SP9, pye Unicam, UK). Phosphorus was estimated colorimetrically by ammonium molybdate method. Vitamin A ( $\beta$ - carotene) was determined using acetone - petroleum ether $\left(40-60^{\circ} \mathrm{C}\right)$ in the ratio $1: 3$ as a solvent as described by [11]. Ascorbic acid (Vitamin C) was determined by titration against 2,6-dichlorophenol indophenols as described by [12]. Determination of the amino acid profile consists of two steps: Hydrolysis of the protein to constituent's amino acids and the quantitative estimation of the amino acids in the hydrolysate, using the Technicon Sequential Analyzer Union Carbide Corp., New York, N.Y. (TSM). The DPPH radical scavenging activity of the samples was determined according to the method of Mensor et al. [13]. The breaking strength (load at break), hardness (energy at break) and toughness (extension at break) of the 'kokoro' was measured using Universal Testing Machine (model M500-50KN, Testometric, England) according to the method described by [14].

\subsection{Statistical Analysis}

All determinations were performed in triplicate and the results are expressed as means values \pm standard deviations (SD). The data were subjected to statistical analysis using statistical program package STATISTICA. The one-way analysis of variance (ANOVA) followed by Duncan multiple range test were employed and the differences between individual means were deemed to be significant at $P<0.05$.

\section{RESULTS AND DISCUSSION}

The proximate composition (dry matter basis) of ginger spiced 'kokoro' is shown in Table 1 Moisture content (\%) of ginger spiced 'kokoro' varied significantly, values fell within the recommended moisture content of snack pellets 10 and 14\% [15]. Low moisture content is desirable in such snacks, as high moisture content could result in crispiness of the snack, and accelerate other biochemi- 
cal changes such as oxidative rancidity. Addition of ginger and or soy flour resulted in significant increase increase in the crude fiber, crude fat and protein content of 'kokoro'. The increase in the fat content might be attributed for the fact that soy flour is rich in oil. Values obtained for the protein content were fairly comparable to the recommended protein level of $18 \%-20 \%$ [16]. Addition of soy resulted in significant increase in the calculated energy content of 'kokoro' this might be attributed to the oil in the snack which is a good source of energy. As indicated in Table 2, Addition of soy and or ginger powder resulted in significant increase in the $\mathrm{Ca}, \mathrm{Mg}, \mathrm{P}$,
$\mathrm{Na}$ and $\mathrm{K}$, of 'kokoro' The $\mathrm{Na} / \mathrm{K}$ ratio in the body is important because it helps in controlling high blood pressure $\mathrm{Na} / \mathrm{K}$ ratio values compares favourably with the recommended value of less than one [17]. Nieman et al., [18] considered a food source good if the $\mathrm{Ca} / \mathrm{P}$ ratio is above 1 and poor if the ratio is less than 0.5 . The maize snack 'kokoro' happen to be good food source $(\mathrm{Ca} / \mathrm{P}$ ratio ranged from $0.5-1.5)$ for minerals used in bone formation. The presence of soy flour and ginger increased the vitamin $\mathrm{C}$ and A contents of ginger spiced 'kokoro' in comparison with the control (Figures 1 and 2). The

Table 1. Proximate composition of 'kokoro' substituted with soy flour and ginger spice (\% dry matter basis).

\begin{tabular}{cccccccc}
\hline SAMPLES & $\begin{array}{c}\text { MOISTURE } \\
(\%)\end{array}$ & $\begin{array}{c}\text { ASH } \\
(\%)\end{array}$ & $\begin{array}{c}\text { CRUDE FAT } \\
(\%)\end{array}$ & $\begin{array}{c}\text { CRUDE } \\
\text { FIBRE (\%) }\end{array}$ & $\begin{array}{c}\text { CRUDE } \\
\text { PROTEIN (\%) }\end{array}$ & $\begin{array}{c}\text { CARBOHYDRATE } \\
(\%)\end{array}$ & $\begin{array}{c}\text { CALCULATED ENERGY } \\
\text { VALUE (KJ/g) }\end{array}$ \\
\hline $\mathrm{WM}$ & $10.71 \pm 0.01^{\mathrm{d}}$ & $1.88 \pm 0.00^{\mathrm{d}}$ & $20.92 \pm 0.01^{\mathrm{f}}$ & $1.04 \pm 0.00^{\mathrm{f}}$ & $8.32 \pm 0.00^{\mathrm{f}}$ & $57.13 \pm 0.00^{\mathrm{a}}$ & $1887 \pm 0.00^{\mathrm{d}}$ \\
$\mathrm{WM} / \mathrm{WG}$ & $12.19 \pm 0.01^{\mathrm{b}}$ & $1.74 \pm 0.01^{\mathrm{e}}$ & $27.01 \pm 0.01^{\mathrm{d}}$ & $1.09^{\mathrm{e}} \pm 0.00$ & $10.05 \pm 0.00^{\mathrm{e}}$ & $47.92 \pm 0.02^{\mathrm{c}}$ & $1985 \pm 0.33^{\mathrm{bc}}$ \\
$\mathrm{WM} / \mathrm{YG}$ & $11.04 \pm 0.01^{\mathrm{c}}$ & $2.14 \pm 0.01^{\mathrm{b}}$ & $23.05 \pm 0.01^{\mathrm{e}}$ & $1.15 \pm 0.01^{\mathrm{d}}$ & $10.96 \pm 0.01^{\mathrm{d}}$ & $51.65 \pm 0.03^{\mathrm{b}}$ & $1917 \pm 0.33^{\mathrm{d}}$ \\
$\mathrm{WM} / \mathrm{S} / \mathrm{WG}$ & $10.15 \pm 0.01^{\mathrm{e}}$ & $1.94 \pm 0.01^{\mathrm{c}}$ & $29.98 \pm 0.01^{\mathrm{b}}$ & $1.23 \pm 0.01^{\mathrm{b}}$ & $13.11 \pm 0.03^{\mathrm{c}}$ & $43.59 \pm 0.04^{\mathrm{d}}$ & $2000 \pm 73.17^{\mathrm{bc}}$ \\
$\mathrm{WM} / \mathrm{S} / \mathrm{YG}$ & $12.47 \pm 0.01^{\mathrm{a}}$ & $2.19 \pm 0.00^{\mathrm{a}}$ & $29.86 \pm 0.01^{\mathrm{c}}$ & $1.25 \pm 0.01^{\mathrm{a}}$ & $13.60 \pm 0.00^{\mathrm{b}}$ & $40.63 \pm 0.02^{\mathrm{e}}$ & $2027 \pm 0.00^{\mathrm{b}}$ \\
$\mathrm{WM} / \mathrm{S}$ & $9.25 \pm 0.01^{\mathrm{f}}$ & $1.36 \pm 0.01^{\mathrm{f}}$ & $31.72 \pm 0.03^{\mathrm{a}}$ & $1.21 \pm 0.00^{\mathrm{c}}$ & $15.91 \pm 0.01^{\mathrm{a}}$ & $40.54 \pm 0.04^{\mathrm{e}}$ & $2135 \pm 0.88^{\mathrm{a}}$ \\
\hline
\end{tabular}

Values represent means of triplicates. Values in a column with same superscript are not significantly different at $p \leq 0.05$. NOTE: WM $=\mathrm{White} \mathrm{Maize}$; WM/WG = White Maize: White Ginger; WM/YG = White Maize: Yellow Ginger; WM/S/WG = White Maize: Soy bean: Yellow Ginger; WM/S/YG = White Maize: Soy bean: Yellow Ginger; WM/S = White Maize: Soy bean.

Table 2. Mineral composition of ginger spiced 'kokoro'.

\begin{tabular}{|c|c|c|c|c|c|c|c|}
\hline Samples & $\begin{array}{c}\text { Ca } \\
\text { (mg/100 g) }\end{array}$ & $\begin{array}{c}\text { Mg } \\
(\mathbf{m g} / \mathbf{1 0 0} \mathrm{g})\end{array}$ & $\underset{(\mathrm{mg} / 100 \mathrm{~g})}{P}$ & $\stackrel{\mathrm{Na}}{(\mathrm{mg} / 100 \mathrm{~g}}$ & $\underset{(\mathrm{mg} / 100 \mathrm{~g})}{\mathrm{K}}$ & $\mathrm{Na} / \mathrm{K}$ & $\mathbf{C a} / \mathbf{p}$ \\
\hline WM & 352 & 191 & 272 & 293 & 380 & 0.8 & 1.3 \\
\hline $\mathrm{WM} / \mathrm{WG}$ & 410 & 205 & 277 & 298 & 605 & 0.5 & 1.5 \\
\hline WM/YG & 438 & 297 & 318 & 345 & 412 & 0.8 & 1.4 \\
\hline $\mathrm{WM} / \mathrm{S} / \mathrm{WG}$ & 309 & 299 & 625 & 1517 & 1882 & 0.8 & 0.5 \\
\hline $\mathrm{WM} / \mathrm{S} / \mathrm{YG}$ & 492 & 394 & 811 & 1610 & 1904 & 0.8 & 0.6 \\
\hline $\mathrm{WM} / \mathrm{S}$ & 488 & 366 & 713 & 1500 & 1978 & 0.8 & 0.7 \\
\hline
\end{tabular}

Values represent means of triplicates. KEYS: $\mathrm{WM}=$ White Maize; WM/WG $=$ White Maize: White Ginger; WM/YG = White Maize: Yellow Ginger; $\mathrm{WM} / \mathrm{S} / \mathrm{WG}=$ White Maize: Soy bean: Yellow Ginger; WM/S/YG = White Maize: Soy bean: Yellow Ginger; WM/S = White Maize: Soy bean.

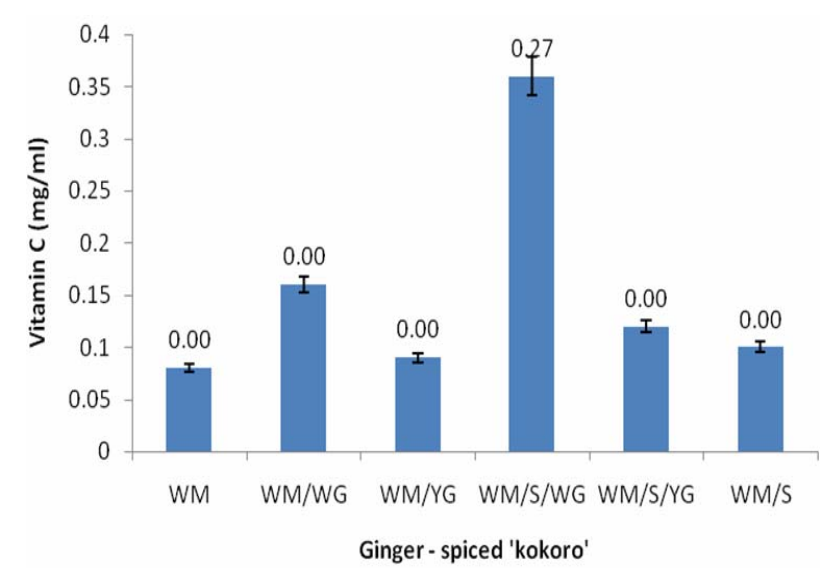

Figure 1. Vitamin C content of Ginger spiced 'kokoro'.

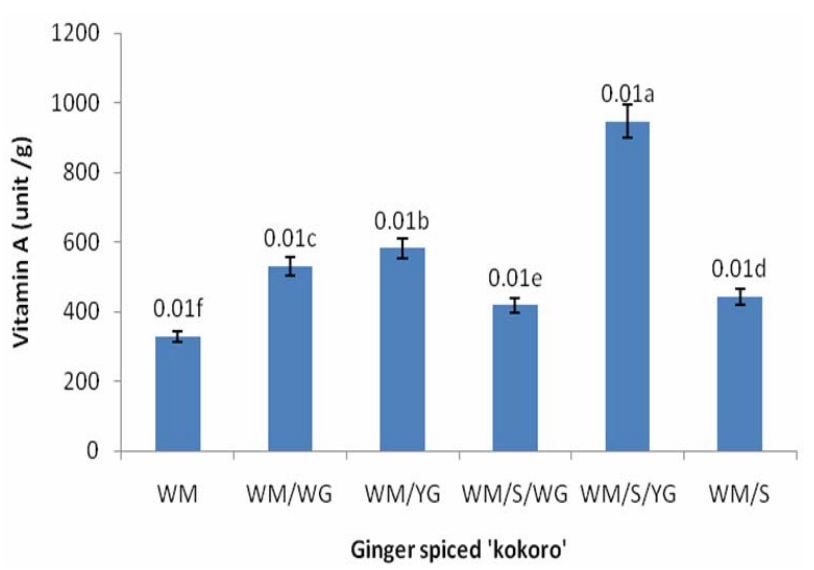

Figure 2. Vitamin A content of Ginger spiced ‘kokoro’. 
presence of white ginger increases vitamin $\mathrm{C}$ significantly while the presence of yellow ginger increases the vitamin A content. Vitamin C provides a protective function against free radicals. Average daily intake level that is sufficient to meet the nutritional requirement of ascorbic acid or recommended dietary allowances (RDA) for adults (> $19 \mathrm{yr}$ ) are $90 \mathrm{mg} /$ day for men and $75 \mathrm{mg} /$ day for women [19]. Ginger spiced 'kokoro therefore could not be referred to as a good source of vitamin C. The presence of yellow ginger increases the vitamin A content of ginger spiced 'kokoro. The obtained results on the DPPH radical scavenging activities of ginger spiced 'kokoro' are shown in Figure 3. The extract of ginger spiced 'kokoro showed a significant effect in inhibiting DPPH. Increase of $11 \%$ had been observed in DPPH scavenging activities of $\mathrm{WM} / \mathrm{S} / \mathrm{YG}$, when compared with WM. The antioxidant activity of plant extracts containing polyphenol components is due to their capacity to be donors of hydrogen atoms or electrons and to capture the free radicals.

DPPH analysis is one of the tests used to prove the ability of the components of the ginger spiced 'kokoro' extract to act as donors of hydrogen atoms and to capture free radicals.

The amino acid composition of ginger spiced 'Kokoro is shown on Table 3.

Leucine is the most predominant essential amino acid in the ginger spiced 'kokoro'. These observation are in agreement with the observations made earlier by Aremu et al., [20] and Olaofe, et al., [21], suggesting Leucine as the most concentrated essential amino acid in Nigerian plant foods. Glutamic is the most concentrated non essential amino acid. Total essential amino acid in the ginger spiced 'kokoro' ranged from 18.40 to 29.57 $\mathrm{g} / 100 \mathrm{~g}$ protein; the highest was observed in $\mathrm{WM} / \mathrm{S} / \mathrm{YG}$. This implies that yellow ginger (YG) has higher total essential amino acid than the white ginger (WG). The nutritive value of a protein depends primarily on the capacity to

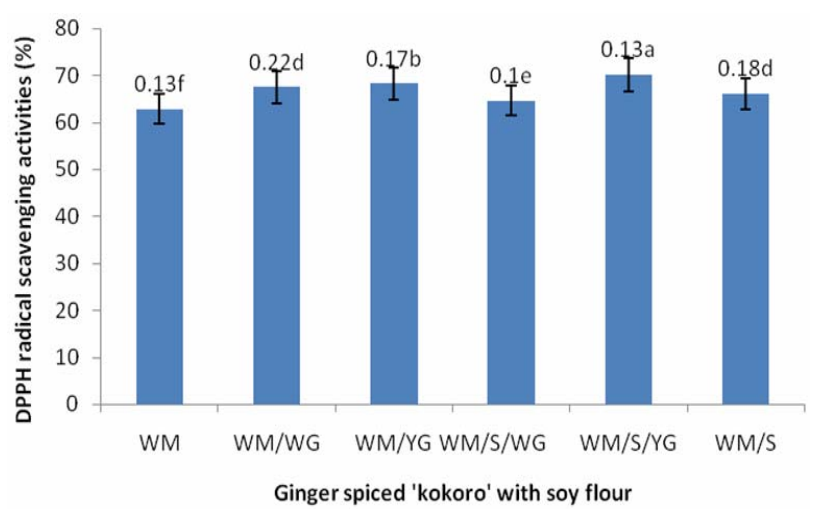

Figure 3. DPPH radical scavenging activities of ginger spiced 'Kokoro'. satisfy the needs for nitrogen and essential amino acids [21]. TSAA for the ginger spiced 'kokoro' is higher than the $5.8 \mathrm{~g} / 100 \mathrm{~g}$ crude protein recommended for infants [22], which makes ginger spiced 'kokoro' an ideal snack for infants.

The textural profile of ginger spiced 'kokoro' is shown in Table 4. Texture is a very important quality characteristic which makes a significant contribution to the overall quality acceptance of food products.

Table 3. Amino acid composition of Ginger spiced 'kokoro'.

\begin{tabular}{|c|c|c|c|}
\hline Amino acid & $\begin{array}{c}\text { WM/S/WG } \\
\text { (g/100 g } \\
\text { protein) }\end{array}$ & $\begin{array}{c}\text { WM/S/YG } \\
\text { (g/100 g } \\
\text { protein) }\end{array}$ & $\begin{array}{l}\text { WM/S } \\
\text { (g/100 g } \\
\text { protein) }\end{array}$ \\
\hline Tyrosine & 2.86 & 3.02 & 3.02 \\
\hline Methionine & 0.68 & 0.89 & 1.12 \\
\hline Threonine & 2.48 & 2.71 & 3.04 \\
\hline Valine & 2.86 & 3.29 & 3.41 \\
\hline Phenylalanine & 3.23 & 4.02 & 3.93 \\
\hline Isoleucine & 2.06 & 2.95 & 2.89 \\
\hline Leucine & 7.15 & 8.60 & 9.15 \\
\hline Lysine & 3.13 & 3.16 & 3.24 \\
\hline Cystine & 0.79 & 0.93 & 0.99 \\
\hline Tryp & ND & ND & ND \\
\hline Total Ess. AA & 25.24 & 29.57 & 18.40 \\
\hline Histidine & 1.89 & 2.21 & 2.30 \\
\hline Arginne & 3.54 & 3.88 & 3.97 \\
\hline Aspartic Acid & 5.12 & 6.11 & 6.14 \\
\hline Serine & 2.20 & 2.79 & 2.82 \\
\hline Glutamic Acid & 6.59 & 7.50 & 8.18 \\
\hline Proline & 2.85 & 3.36 & 3.36 \\
\hline Glycine & 2.79 & 2.91 & 3.15 \\
\hline Alanine & 3.00 & 3.19 & 3.38 \\
\hline Isoleucine & 2.06 & 2.95 & 2.89 \\
\hline Total Non Ess. AA & 30.04 & 34.9 & 36.19 \\
\hline Total (TEAA + TNEAA) & 55.28 & 64.47 & 54.59 \\
\hline TEAA/TNAA \% & 0.84 & 0.85 & 0.51 \\
\hline TEAA/ТАA \% & 0.46 & 0.46 & 0.34 \\
\hline TSAA (Meth +Cys) & 1.47 & 1.82 & 2.11 \\
\hline Ar EAA (Phe + Tyr) & 6.09 & 7.04 & 6.95 \\
\hline
\end{tabular}

Table 4. Textural profile of ginger spiced 'kokoro'.

\begin{tabular}{cccc}
\hline Samples & $\begin{array}{c}\text { Load at } \\
\text { Break (N) }\end{array}$ & $\begin{array}{c}\text { Compressed Extension } \\
\text { at Break (mm) }\end{array}$ & $\begin{array}{c}\text { Energy at } \\
\text { break (J) }\end{array}$ \\
\hline $\mathrm{WM}$ & $\mathbf{8 . 1 1}$ & 5.12 & 0.04 \\
$\mathrm{WM} / \mathrm{S} / \mathrm{WG}$ & 2.60 & 3.0 & 0.01 \\
$\mathrm{WM} / \mathrm{S} / \mathrm{YG}$ & 5.09 & 2.8 & 0.01 \\
$\mathrm{WM} / \mathrm{S}$ & 3.60 & 4.7 & 0.03 \\
\hline
\end{tabular}


It was one of the three main acceptability factors used by consumers to evaluate food, the other two being appearance and flavor [23]. The load at break (N) is the maximum or peak compressive force experienced by the food sample during a compression test. The values obtained, for load at break (N), Compressed Extension at Break $(\mathrm{mm})$, and the energy at break $(\mathrm{J})$ decreases with the addition of soy and or ginger powder. The implication of this observation is that a lower force, lower energy would be required to break the ginger spiced 'kokoro'. The fragilility of the ginger - spiced 'kokoro' will be a desirable textural quality.

The research had successfully provided infornation on the nutritional and textural properties of ginger spiced maize snack 'kokoro.

\section{ACKNOWLEDGEMENTS}

This study was funded under the auspices of STEP B., Centre For Excellence in Food Security Research grant of the Federal University of Technology, Akure, Nigeria.

\section{REFERENCES}

[1] Central Bank of Nigeria (1992) Annual Report and Statement of Accounts. Central Bank of Nigeria, Lagos, p.78.

[2] Okaka, J.C (2005) Basic Processing of Grain Cereals and Legumes in Handling, Storage and Processing of Plant Foods. OCJ Academic Publishers, Enugu, Nigerian, $30-60$.

[3] Almeida-Dominguez, N.G., Valencia. M.E., Higuera- Cia para, I. (1990) Formulation of corn-based snacks with high nutritive value: Biological and sensory evaluation. Journal of Food Science, 55, 228-331. doi:1111/j.1365-2621.1990.tb06058.x.

[4] Omueti, O. and Morton, I.D. (1996) Development by extrusion of soybean snack sticks a nutritionally improved soya-maize products based on the nigeria snack (Kokoro). International Journal of Food Science and $\mathrm{Nu}$ trition, 47, 5-13. doi:10.1080/09637480701566495

[5] Rosa, N., Chávez-Jáuregui, R.A.C., Maria, E.M., Pinto, E.S. and Jose, A.G.A. (2003) Acceptability of snacks produced by the extrusion of amaranth and blends of chickpea and bovine lung. International Journal of Food Science and Technoloogy, 38, 795-798.

$$
\text { doi:10.1046/j.1365-2621.2003.00734.x }
$$

[6] Willey, A.O. (1974) Ginger growing in queensland. queensland agriculture journal, 100, 551-558

[7] Meadow, A. B. (1988) Ginger processing for food and for industry. Project paper FIIRO, Lagos, Nigeria.

[8] Guyer, D. (2003) Advanced Medical Centre, Zionsville, Indiana, Indianapolis, USA.
[9] Rodriquez, D.W. (1991) A Short economics history of ginger commodity, Bulletin No. 4, Agricultural planning unit, Ministry of Agriculture and Fisheries, Jamaica.

[10] Ibanga, U.I. and Oladele, A.K. (2008) Production and determination of the proximate composition and consumer acceptability of an enriched dumpling (masovita) made of maize, soybeans and cassava. Journal of Applied Biosciences, 6, 180-183.

[11] AOAC. (2000). Official Methods of Analysis. 17th Edn., Association of Official Analytical Chemists, Washington, DC.

[12] Robinson, W.B. and Stotz, E. (1945) The indeophenolxylene extraction method for ascorbic acid and modifications for interfering substances. The Journal of Biological Chemisty, 160, 217-225.

[13] Mensor, L.L., Menezes, F.S., Leitao, G.G., Reis, A.S., dos Santos, T.C., Coube, C.S. and Leitao, S.G. (2001) Screening of brazilian plant extracts for antioxidant activity by the use of DPPH free radical method. Phytotherapy Research, 15, 127-130. doi:10.1002/ptr.687

[14] Bajaj, S. (2004) Antioxidative properties of mint (Mentha spicata L.) and its application in biscuits. MScdissertation, University of Mysore (2004).

[15] Guzman, A.Q. (2012) GMPs in the snack food industry in Latin America. Food Safety Magazine. April/ May.

[16] FAO of the United Nations (1996) Grain Legumes in Africa 3rd edition. Food and Agricultural Organization, Rome, 82 - 83.

[17] National Research Council (1989) Recommended Dietary Allowances, National Academy Press, Washington, DC, USA,

[18] Nieman, D.C., Butterworth, D.E. and Nieman, C.N. (1992) Nutrition, Wm C. Brown Publishers. Dubugye, USA, 237-312.

[19] Frei, B. and Traber, M. (2001) The new US dietary reference for vitamins C and E. Redox Report, 6, 5-9. doi: $10.1179 / 135100001101535978$

[20] Aremu, M.O., Olaofe, O., Basu, S.K., Abdulazeez, G. and Acharya, S.N. (2010) Processed cranberry bean (Phaseolus coccineus L.) seed flour for the African diet. Canadian Journal of Plant Science, 90, 719-728. doi:10.4141/CJPS09149

[21] Olaofe, O., Okiribiti, B.Y. and Aremu, M.O. (2008) Chemical evaluation of the nutritive value of smooth luffa (Luffa cylindrica ) seed's kernel. Electronic Journal of Environmental, Agricultural and Food Chemistry,7, 3444-3452,

[22] Salunkhe, D.K., Kadam, S.S. and Chavan, J.K., CRC Postharvest biotechnology of food legumes, CRC Press, Boca Raton, Fla, USA, 1985.

[23] Bourne, M.C. (1990) Basic principles of food texture measurement. Dough Rheology and Baked Product Texture, 331-342. doi:10.1007/978-1-4613-0861-4 6 